\title{
Literêre genre van die Daniëlverhale ${ }^{1}$
}

\author{
M. Nel \\ Departement Ou Testament \\ Universiteit van Pretoria \\ PRETORIA \\ E-pos:mnmnmn@webmail.co.za
}

\begin{abstract}
Literary genre of the stories in die Book of Daniel

The literary genre of the stories in the book of Daniel has acquired a central position in modern research. Most researchers agree that the stories contain material that is older than the visions contained in Daniel 7-12. Corresponding to the narrative of Daniel and his three friends the following can be listed: the biblical stories of Joseph and Esther; the Assyrian story of Ahikar; the stories of Tobit and Judith; Daniel and Susannah; Daniel, Bel and the Snake; and the story in 1 Esdras 3:1-4:63. The issue regarding the genre of these narratives thus should be addressed. The article proposes that the Daniel stories be read as wisdom literature. Furthermore, the different opinions of the following researchers are discussed: W.L. Humphreys, J.J. Collins, R.R. Wilson, P.R. Davies, G.W.E. Nickelsburg, as well as S. Niditch and $R$. Doran. The conclusion arrived at is that no consensus on the classification of the genre of the stories exists and that the lack of a standardised system in the classification of genre hampers the discussion.
\end{abstract}

\section{Inleiding}

Die vraag na die genre van die Daniëlboek as 'n geheel, en van die verhale in die eerste ses hoofstukke, het as een van die sentrale kwessies in moderne navorsing na vore gekom (Collins, 1984:28). Daar is redelike eenstemmigheid dat die verhale in die eerste ses hoofstukke gegewens bevat wat ouer as die gegewens in Daniël 7-12 is. Navorsers noem dat die verhale oor Daniël en sy drie vriende in verskeie opsigte ooreenstem met 'n aantal Bybelse en nie-Bybelse verhale. So word daar op die verband met die verhale van Josef en Ester asook die Assiriese Agikarstorie gewys. Ander verhale wat 'n ooreenkoms vertoon, is dié van

1 Dié artikel is gebaseer op navorsing wat onder leiding van prof. D.J. Human in 1999 en 2000 gedoen is, en vervat is in 'n proefskrif getitel "'n Teologies-hermeneutiese ondersoek na Daniël 1 en 2" vir die Ph. D.-graad by die Universiteit van Pretoria. 
Tobit, Judith, Daniël en Susanna, Daniël, Bel en die Slang en die verhaal van Darius se drie lyfwagte in 1 Esdras 3:1-4:63 (Nickelsburg, 1972:4858; Humphreys, 1973:211; Collins, 1975:219; Hartman \& DiLella, 1978: 55-61 en Porteous, 1979:16).

Navorsers stem oor dié sake ooreen, maar wanneer dit kom by 'n bepaling van die genre van die Daniëlverhale en die verwante literatuur, is daar weinig ooreenstemming. Een van die grootste probleme is dat daar nie 'n standaardgenre-indeling bestaan wat deur alle navorsers aanvaar word nie.

Die Daniëlverhale se genre is al beskryf as:

- haggadiese verhale (Bentzen, 1952:11; LaCocque, 1979:26);

- godsdienstige of populêre verhale (Heaton, 1956:32-47; Gammie, 1976:193);

- wysheidsverhale (Scott, 1971:95; Nickelsburg, 1972:55);

- hofverhale (Humphreys, 1973:220; Collins, 1975:219; Niditch \& Doran, 1977:179);

- wonderwerkverhale (Hengel, 1974:111);

- aangepaste martelaarsverhale (Hartman \& DiLella, 1978:58; Porteous, 1979:55);

- midrasj-verhale (Hartman \& DiLella, 1978:55);

- hoflegendes (Collins, 1984:42; 1985:134);

- komedie (Good, 1985:47-56).

Hierdie is nie waterdigte onderskeidings nie, want daar is oorvleuelings in die geleerdes se klassifikasies. Dit hang saam met die gebrek aan 'n standaard vormkritiese genreterminologie. Dit is duidelik dat die meerderheid navorsers meen die verhale in Daniël 1-6 hoort by die genre van wat algemeen wysheidsliteratuur genoem word. Van die talle subklassifikasies wat gebruik word om die verhale binne die wysheidskategorie te plaas, is die mees gekose genre die hofverhaal.

Heaton (1956:40) meen die ses verhale, saam met ander verhale soos Josef en Agikar, vorm "a distinct literary type". Die vraag is: wat is die eienskappe wat dié literêre tipe kenmerk? Verskeie antwoorde is hierop gegee, waarvan ek die belangrikste kortliks bespreek.

In dié artikel word enkele belangrike bydraes tot die debat oor die genrebepaling van die Daniëlboek bespreek, voor enkele gevolgtrekkings gemaak word. 


\section{Verskeie standpunte}

\subsection{G.W.E. Nickelsburg}

Nickelsburg (1972:48-58) ondersoek Daniël 3 en 6 in sy navorsing oor die teologie van opstanding, onsterflikheid en die ewige lewe in die intertestamentêre tyd. Hy aanvaar dat teologiese konsepte dikwels binne spesifieke vorme gedra word, en stel hom ten doel om dié vorme te ondersoek.

Nickelsburg kyk na die verhaal van die vervolging en verhoging van die regverdige in Wysheid 2 en 4-5, en poog om die Gattung van die storie te vestig deur dit te vergelyk met parallelle in Israel se godsdienstige literatuur (Nickelsburg, 1972:48). Hy ondersoek hiervoor die Josefverhale in Genesis 37-42, die Agikarverhaal, die verhaal van Ester en Mordegai, die verhaal van Susanna, en Daniël 3 en 6. Dit is almal voorbeelde van dieselfde Gattung wat deur Nickelsburg (1972:55) as die wysheidsverhaal geïdentifiseer word. Al dié verhale vertoon dieselfde tema, agtergrond, karaktertipes, narratiewe tegniek en struktuur. Hy ontwikkel 'n strukturele skema vir die wysheidsverhaal wat uit agtien elemente bestaan: "reason, conspiracy, accusation, trial, helper(s), choice, condemnation, ordeal, protest, trust, reactions, rescue, exaltation, reactions, acclamation, vindication, punishment, confession". Geen verhaal bevat al agtien elemente nie. In die verhaal van Daniël 3 kom vyf van die elemente kort, naamlik "reason, conspiracy, helpers, protest, confession", en by dié in Daniël 6 ontbreek drie: "trial, protest, confession". 2

Nickelsburg se beskrywing van die Gattung as "wysheidsverhaal" is minder spesifiek en breedvoeriger as die beskrywing "hofverhaal". Die patroon van die verhaaltipe met sy agtien elemente is meer gedetailleerd as ander skemas. Die elemente self is minder inhoudelik spesifiek.

Tog is daar by verdere ondersoek duidelike ooreenkomste met die bevindinge van ander studies. So kom Nickelsburg se element "reason" voor by Collins se eerste punt onder konflikverhale, "die helde is in 'n staat van voorspoed" (vgl. 2.3). Die elemente "conspiracy, accusation, reaction, trial, choice" stem ooreen met Collins se tweede punt, "die helde word bedreig". Die element "condemnation" stem met Collins se derde punt ooreen en "rescue" met sy vierde punt.

$2 \quad$ Nickelsburg se hoofteks, Wysheid 2 en 4-5, bevat dertien van die agtien elemente. Tog meen hy hoort dit nie by die Gattung "wysheidsverhaal" nie. Hy bevind dat die vorm van die wysheidsverhaal hier verander is. Dit verskil "stilisties" van die wysheidsverhaal (Nickelsburg, 1972:67, 90). 
"Vindication, acclamation, exaltation" kom met sy vyfde punt ooreen. Nickelsburg se studie bevat egter 'n inkonsekwentheid tussen die identifikasie van die elemente in individuele stories en sy opsomming van elemente, terwyl hy ook te min aandag aan die orde of patroon van die elemente gee. Dit is ook nie duidelik wat die skrywer met die terme "vorm" en "elemente" bedoel nie. Nickelsburg verskaf nêrens 'n definisie en beskrywing van die Gattung "wysheidsverhaal" nie. Sy strukturele kategorieë bly net so aan inhoud gekoppel as enige van die ander navorsers (kyk Milne, 1988:190-191 vir verdere kritiek). ${ }^{3}$

\subsection{W.L. Humphreys}

Humphreys (1973:211-223) analiseer op sy beurt die verhale van Ester en Daniël om aan te toon dat dié twee boeke gebaseer is op verhale van 'n besondere tipe. Saam met die verhale van Nehemia, Agikar en Josef vorm dit 'n ooreenstemmende literêre tipe wat Humphreys (1973:217) "the tale of the courtier" noem. Dié verhale, meen Humphreys (1973: 213), was populêr onder Diaspora-Jode, selfs al het die verhale nie oor Joodse figure gehandel nie. 4

Die verhaal van die howeling is volgens Humphreys gekenmerk deur 'n patroon of struktuur wat gedeel word deur alle verhale wat tot dié tipe behoort. Daar is vyf basiese elemente in die patroon:

- In die sentrum van die verhaal is 'n howeling met uitmuntende eienskappe waarvoor hy gou erkenning kry.

- Hierdie howeling vind sy plek in die koninklike hof van die spesifieke tyd.

- Die lewe van die howeling word bedreig deur die bose sette van ander howelinge of deur omstandighede aan die hof.

$3 \quad$ Kyk Rhoads en Michie (1982:4) se opmerking dat, ten einde 'n anaise te kan maak, 'n duidelike onderskeid tussen die inhoud van die narratief, die storie, die vorm van die narratief en die retoriek nodig is. "The story refers to 'what' a narrative is about - the basic elements of the narrative world - events, characters, and setting. Rhetoric refers to 'how' that story is told in a given narrative in order to achieve certain effects upon the reader. Thus we can distinguish between 'what' the story is about and 'how' the story is told". Die "wat" en "hoe" is onafskeidbaar deel van mekaar. Wanneer gepoog word om 'n analise te maak, blyk dit egter onmoontlik te wees om die "wat" en die "hoe" te onderskei. Dit lyk asof dit 'n basiese probleem by die bespreking van die genrevraagstuk van die Daniëlverhale is wanneer die inhoud en vorm nie duidelik onderskei word nie, sodat die inhoud as enigste maatstaf in die bespreking dien.

$4 \quad$ Ongelukkig teoretiseer Humphreys nie oor die rede vir dié gewildheid nie. Hy bied ook nie verdere bewyse vir sy stelling dat dit gewild was nie, buiten vir die feit dat verskeie verhale met dié tema in dié tyd ontstaan. 
- Die howeling is in staat om die bedreiging te oorkom deur die omstandighede te oorwin of die sette van kollegas te omseil, en hy word weer aan die hof in ere herstel.

- Die howeling word tot 'n hoër rang verhef en beloon, terwyl sy vyande gestraf word (Humphreys, 1973:217).

Dié patroon vorm die basiese vorm van die hofverhaal. Humphreys (1973:217) onderskei verder twee subtipes, wat hy "verhale van hofkonflik" en "verhale van hofwedywering" ("tales of court conflict" en "tales of court contest") noem. Die verskil tussen die twee subtipes lê in die manier waarop die derde en vierde elemente van die basiese vorm gerealiseer word. Die bron van die gevaar wat die howeling bedreig, asook die wyse waarop die gevaar oorkom word, bepaal of 'n gegewe howelingverhaal een van hofkonflik of een van hofgeskil is.

Elke subtipe het sy eie skema of patroon. In verhale van hofgeskille kom 'n geveg voor tussen die howeling en sy vyandige kollegas, waarin die howeling wen. Die howeling word beloon vir sy sukses en die ander word gestraf. Die verhaal sluit met die erkenning van die suksesvolle held. Daniël 2, 4 en 5 word deur Humphreys (1973:219) hieronder geplaas. ${ }^{5}$

In verhale van hofkonflik kom daar 'n stryd voor waarin een faksie die ander wil vernietig. Die konflik word op 'n manier hanteer, en die een kant word beloon terwyl die ander party gestraf word.

Humphreys (1973:219) kategoriseer Daniël 3 en 6 as hofkonflikverhale. ${ }^{6}$

Humphreys se studie is belangrik omdat dit nie bloot die literêre tipe van die verhale van Daniël 1-6 identifiseer nie. Hy bied ook 'n beskrywing van daardie tipe, in sy basiese vorm sowel as sy variëteite of subtipes. Kritiek wat Milne (1988:182) daarteen uitspreek, en wat 'n tekortkoming blyk te wees, is dat dit nie die basiese terme soos "tipe", "vorm", "struktuur" en "subtipe", behoorlik definieer nie.

Humphreys verklaar nie die aard van die kategorieë wat hy gebruik nie. Hy verduidelik ook nie watter kriteria hy gebruik om elemente in sy patrone of strukture te identifiseer nie. Die patrone wat hy identifiseer, word volledig beskryf aan die hand van die elemente van die inhoud wat hy in verskeie verhale in sy groep isoleer.

5 En so ook die deel van die Josefverhaal wat in Genesis 40-41 voorkom.

6 En so ook die Agikarverhaal, die verhaal van Ester en Mordegai, asook elemente van die Nehemiaverhaal. 


\subsection{J.J. Collins}

Collins het drie onderskeie ondersoeke van Daniël 1-6 onderneem. In sy eerste ondersoek wou hy die integrasie van ouer materiaal in die Daniëlverhale soos dit vandag voorkom, navors. As deel van sy ondersoek kyk hy ook na die aard en doel van die verhale. Hy identifiseer dit as "hofverhale". Hy verdeel die hofverhale in kleiner groepe op grond van "various motifs" wat in die verhale voorkom (Collins, 1975:219). Die volgende drie motiewe of beklemtonings geld in Daniël 1-6:

- Die verhaal beklemtoon die wysheid of vermoë van die howeling.

- Die verhaal fokus op die drama van gevaar of vernedering wat deur uitredding gevolg word.

- Die verhaal word gebruik as instrument om die boodskap van die howeling weer te gee.

In navolging van Humphreys se onderskeiding identifiseer Collins die eerste groep met die verhale van hofgeskille, en die tweede groep met die verhale van hofkonflik. Die verhaal in Daniël 2 behoort aan die eerste groep. Die klem val op die wysheid van Daniël en sy God, en die werklike inhoud van die droom word daartoe gerelativeer (Collins, 1975: 220).

Die verhale in Daniël 1, 3 en 6 is "verhale van uitredding" en hoort by die tweede groep waarin die drama van gevaar deur redding gevolg word. Dié verhale volg 'n patroon waarin die vier volgende elemente onderskei kan word:

- die helde is in 'n situasie van voorspoed en welvaart;

- hulle word bedreig, gewoonlik deur 'n sameswering;

- hulle word tot die dood of gevangenis veroordeel;

- hulle word vrygelaat, hul wysheid erken en hulle word in ere herstel.

Die laaste twee verhale - dié in Daniël 4 en 5 - word deur Collins beskryf as verhale wat die inhoud van die boodskap beklemtoon, en word as die derde groep geklassifiseer. Verhale in dié groep deel ook 'n patroon wat verskil van die verhale in die tweede groep:

- Die koning word gekonfronteer met drome en tekens wat hy nie verstaan nie.

- Die ander wyse manne kry dit nie reg om dit te ontsyfer nie.

- Daniël slaag waar die ander misluk. 
- Daniël word tot 'n hoë posisie verhef (Collins, 1975:227).

Collins identifiseer nie 'n spesifieke patroon vir die eerste groep nie, maar stel voor dat die eerste en derde groep dieselfde patroon deel. Wat die onderskeid tussen die twee groepe moontlik maak, is nie die patroon nie, maar die hoeveelheid klem wat elk op die inhoud van die boodskap plaas. In Daniël 4 en 5 is die primêre klem op die inhoud van die boodskap, terwyl Daniël 2 die inhoud feitlik ignoreer. Die genre van die verhale in Daniël 1-6 is volgens Collins (1975:219) hofverhale. Dié identifikasie berus op die feit dat die verhale aan 'n koninklike hof afspeel. Nadat hy die genre vasgestel het, maak die navorser subklassifikasies, wat hy "groupings" of "types" noem. Dié groeperinge berus op die basis van dominante motiewe wat in die verhale geïdentifiseer kan word. Die verhale in dié drie groepe deel twee strukture.

In 'n tweede studie ondersoek Collins (1977:27-54) die apokaliptiese visioene in die boek Daniël. Binne dié konteks kyk hy na die individuele hofverhale. Sy klassifikasies is hier effe verskillend. Hy beskou Daniël 1 as inleidende hoofstuk eerder as 'n verhaal wat tot sy tweede tipe, naamlik verhale van uitredding, behoort. Hy meen nie dat dit ' $n$ verhaal is soos die ander vyf verhale nie, maar dat dit eerder die agtergrond skets waarteen die ander verhale afspeel. Volgens Collins verduidelik dié agtergrondinligting hoe Daniël en sy vriende aan die koninklike hof beland, wat hul amptelike rol behels en die probleme wat daaruit voortvloei (Collins, 1977:29). Humphreys (1973:219) het dieselfde standpunt.

Die res van die verhale, meen Collins (1977:52), val in die genre van hofverhale, en kan in twee (eerder as drie) kategorieë verdeel word: verhale van geskille en verhale van konflik (dieselfde as Humphreys se indeling). Die verhale word deur Collins ook op dieselfde manier ingedeel as deur Humphreys. Wat Collins verskillend doen, is om die patroon waaruit die verhale bestaan, duideliker uiteen te sit. Die volgende elemente vorm die patroon van alle geskilverhale:

- Die koning word gekonfronteer met drome en tekens wat hy nie verstaan nie (Dan. 2:1; 4:5; 5:5-7; vgl. ook Gen. 41:7-8).

- Die Babiloniese wyse manne kan nie sin uitmaak van die droom of teken nie (Dan. 2:10-11; 4:7-8; 5:8; ook Gen. 41:8).

- Daniël slaag terwyl die Babiloniese wyse manne misluk (Dan. 2: 2545; 4:19-27; 5:25-29; Gen. 41:25-36).

- Daniël word tot 'n hoë posisie bevorder (Dan. 2:46-49; 5:29; Gen. 41: 39-42 - Collins, 1977:34). 
Collins voeg Daniël 2 by dié kategorie omdat dit dieselfde patroon as Daniël 4 en 5 het, alhoewel die fokus daarvan verskil.

Die patroon wat Collins vir konflikverhale voorstel, het vyf elemente:

- Die helde is in 'n situasie van welvaart (Dan. 3:12; 6:1-3; vgl. ook Gen. 39:1-6; Est. 2:17-19; Agikar is sekretaris van die koning).

- Die helde word bedreig, gewoonlik deur 'n sameswering (Dan. 3:8-18; 6:4-14; Gen. 39:7-19; Est. 3:6; Agikar is die slagoffer van die komplot van Nadan).

- Die helde word tot die dood of gevangenis veroordeel (Dan. 3:19-23; 6:16; Gen. 39:20; Est. 3:13; Agikar 4:4-6).

- Die helde word op grond van verskeie redes vrygelaat (Dan. 3:26; 6:23; Gen. 41:14; Est. 7; Agikar word gespaar en ontbied om die hof se probleem op te los).

- Die wysheid of meriete van die helde word erken en hulle word tot ereposisies verhoog (Dan. 3:29-30; 6:26-28; Gen. 41:37-45; Est. 8:2; Agikar lei 'n suksesvolle sending na Egipte en word deur die farao's en Sanherib vereer - Collins, 1977:50).

Met die bydrae in sy tweede studie los Collins die vraag op wat sy eerste studie gestel het, naamlik wat die verhouding tussen die drie motieftipes en die twee patrone is. In sy tweede studie werk hy egter nie konsekwent nie. Die beskrywing van die elemente word inhoudspesifiek aan die Daniëlverhale gekoppel, sodat dit moeilik is om te sien hoe die ander verhale buite die Daniëlboek bygetrek kan word. Die Josefverhale bied 'n tweede probleem: die Genesis 41-verhaal val onder albei klassifikasies. Dit lei tot die gevolgtrekking dat Collins se analise nie geldig kan wees vir die verhaaltipes nie, omdat die onderskeie patrone duplisering inhou.

In 'n derde ondersoek het Collins (1984) Daniël 1-6 nagegaan binne die konteks van 'n vormkritiese analise van die hele boek. Hy verwys na die werk van Hellholm wat in sy studie van die genresoort van apokaliptiek op die metodes van tekslinguïstiek staatmaak, eerder as op vormkritiek. Hellholm het gevind dat daar ' $n$ behoefte bestaan aan groter differensiasie tussen die abstraksievlakke en tussen die klassifikasiekriteria in die studie van genre. Collins (1984:4) gee toe dat 'n spesifieke literêre vorm as 'n onafhanklike genre of as 'n subtipe van 'n breër kategorie beskou kan word. Hy verkies die kombinasie van formele en inhoudelike eienskappe vir die klassifikasie van tekste volgens genres.

In sy derde ondersoek klassifiseer Collins (1984:41-43) die hele boek as behorende tot die genre van die apokalips, met as subgenre die historiese apokalips. Hy voeg by dat Daniël 1-6 subgenres bevat wat 
vormlik en inhoudelik verskil van Daniël 7-12. Hy klassifiseer Daniël 1-6 as 'n "legende", 'n genre wat volgens hom geen spesifieke struktuur het nie. Legendes het volgens Collins primêr belang by die wonderlike of wonderwerkende, en is gerig op opbouing (Collins, 1984:41). ${ }^{7}$

Collins behou die klassifikasie "hofverhale" met sy twee subkategorieë, maar meen dié tipe klassifikasie verskil van dié van die legende of van die "Märchen" (Collins, 1984:42). Dit is 'n soort klassifikasie wat oor die ander vormkritiese aanwysings sny omdat dit gebaseer is op die agtergrond en komplot, eerder as op die narratiewe wêreld en intensie.

Terwyl daar nie 'n standaardklassifikasiesisteem en gevestigde hiërargie van terminologie bestaan nie, verwar en kompliseer Collins se verdere onderskeidings eerder as om die genrestatus van Daniël 1-6 te verduidelik. ${ }^{8}$

\subsection{S. Niditch en R. Doran}

Die studie van hofverhale kry 'n nuwe impetus met die artikel van Niditch en Doran (1977:179-193). Hul doelstelling is om 'n meer vergelykende benadering tot die probleem van die vorm van hofnarratiewe te volg. Om dit reg te kry, beperk hulle die skopus van hul ondersoek tot 'n klein groepie verhale. Die skrywers meen vorige ondersoeke is gekortwiek deurdat die feit aanvaar is dat Daniël 1-6, Ester, Josef en Agikar verhale is wat tot dieselfde literêre tipe, naamlik hofverhale, behoort. Niditch en Doran konsentreer slegs op Daniël 2, Genesis 41 en Agikar 5-7. Hulle bevind dat dié drie gedeeltes een literêre tipe deel (Niditch \& Doran, 1977:179).

Hierdie twee navorsers kritiseer Humphreys vir wat hulle as sy beskrywing van hofverhale beskou. Hy beskryf die inhoudelike elemente of motiewe en plaas dit in 'n losse versameling gelyk aan mekaar, sonder om uit te brei oor die onderlinge verhoudings wat tussen die elemente bestaan. Humphreys werk sinchronies in die sin dat hy dieselfde elemente uit vergelykbare verhale kristalliseer. Hy ignoreer die diachroniese eise van vormkritiese analise deur geen aandag aan die orde of spesifieke patrone van die motiewe te gee nie (Niditch \& Doran, 1977: 179). Collins gee volgens Niditch en Doran (1977) meer aandag daaraan om die motiefstrukture se buitelyne te skets. Omdat hy egter ' $n$ te groot

7 Jason en Kempinski (1981:20) beskou Daniël 3 en 6 as sakrale legendes, maar klassifiseer nie die res van die Daniëlverhale as legendes nie.

8 Collins (1993:38-52) verdedig in sy kommentaar op die Daniëlboek sy standpunt sonder om iets nuuts daarby te voeg, terwyl hy vanuit sy standpunt kritiek op ander uitspreek. 
groep verhale bestudeer, kan sy benadering nie genoeg gekontroleer word nie (Niditch \& Doran, 1977:180).

Niditch en Doran (1977:180) stel voor dat die beskrywing van 'n literêre tipe op sowel inhoud as struktuur gebaseer moet word. Hul benadering toon ooreenkoms met dié van Aarne en Thompson (1961) in Types of the folktale. Hierin versamel en kategoriseer die skrywers duisende volksverhale ooreenkomstig hul inhoudselemente of motiewe en die struktuur van hul inhoudselemente (Niditch \& Doran, 1977:180).

Die literêre tipe of vorm van die verhale in Daniël 2, Genesis 41 en Agikar 5-7 is reeds deur Aarne en Thompson (1961) beskryf, beweer Niditch en Doran (1977:180). Dit is volksverhale oor wyse manne, wat deur die Aarne-Thompson-verhaaltipe 922 beskryf word as "Clever Acts and Words". Volgens Aarne en Thompson is daar vier primêre komplotgebeure in verhale wat tot Tipe 922 hoort. Elkeen van hierdie primêre komplotgebeure is saamgestel uit 'n kombinasie van motiewe van aksie, karakter, agtergrond, en so meer. Die vier elemente is:

- lemand met 'n laer status word ontbied na 'n persoon met hoër status om te antwoord op moeilike vrae of om 'n probleem wat besondere insig vereis, op te los.

- Die persoon met die hoër status stel die probleem wat niemand anders kon oplos nie.

- Die persoon met 'n laer status los die probleem op.

- Die persoon met die laer status word vergoed daarvoor (Niditch \& Doran, 1977:180).

Binne dié primêre gebeure bestaan verskeie variasies op die basiese motiewe, wat deur die outeurs nuanses genoem word.

Niditch en Doran gebruik die patroon of skema van Aarne-Thompson as 'n maatstaf waarteen hulle die drie verhale meet. Hulle gebruik dit omdat hulle wil beklemtoon dat die inhoud sowel as die inhoudstruktuur belangrik is in die genreklassifikasie van 'n literêre werk.

Hulle vind dat al drie die tekste wat hulle ondersoek - Daniël 2, Genesis 41 en Agikar 5-7 - dieselfde patroon deel. Dié verhale kom tipologies ooreen. Die vraag ontstaan dus in watter opsigte dié verhale verskil van die verhale wat oorspronklik onder Tipe 922 beskryf is. Die volgende kan as moontlike antwoord geld: die hoofbron van variasies tussen die verhale lê in die nuansering van die basiese motiewe van die verhaaltipe. Nuanses is belangrik omdat dit die besondere etos agter die gebruik 
van die betrokke tipe verraai en die nuanses van elke verhaal moet afsonderlik beoordeel en beskryf word.

Nadat die navorsers die nuanserings in die drie verhale ondersoek het, kom hulle tot die gevolgtrekking dat die Agikarverhaal die naaste aan die tradisionele weergawe van Tipe 922 kom. Agikar 5-7 is kultureel genuanseer, maar het dieselfde tema as die tradisionele verhale in Tipe 922. Dit bevat geen besondere godsdienstige of politieke nuanses nie.

Genesis 41 is, soos Agikar 5-7, kultureel genuanseer, maar Genesis 41 het ook 'n godsdienstige nuanse wat dit van die Agikarverhaal sowel as van tradisionele Tipe 922-verhale onderskei. Die godsdienstige nuanse lê in Josef se vermoë om die farao se drome uit te lê. Dié vermoë is deur God aan hom verleen. Hierdie nuanse kom nie in die Aarne-Thompsonkatalogus onder Tipe 922 of in enige van die gelyste verhale voor nie. Genesis 41 verteenwoordig 'n "less traditional use" van Tipe 922 (Niditch \& Doran, 1977:187).

Die verhaal in Daniël 2 staan selfs nog verder van die tradisionele weergawe van Tipe 922 as Genesis 41. Hier word die basiese patroon van Tipe 922 slegs gebruik as raamwerk vir 'n belangriker tema oor die openbaring van die goddelike wil (Niditch \& Doran, 1977:187). Naas die tipiese motiewe van Tipe 922, bevat Daniël 2 nog twee aksiemotiewe (gebed en die antwoord van gebed) en een karaktermotief ('n goddelike helper) wat vreemd aan Tipe 922 is. Hierdie addisionele motiewe het geen plek in die tradisionele wysheidsverhale waarin wyse manne op hulle eie slaag nie (Niditch \& Doran, 1977:190). Motiewe van versoeke om hulp en die voorsiening van hulp deur 'n helper is eerder kenmerkend van Aarne-Thompson se Tipes 300-749. In dié gevalle is die helper en helpende aksie gewoonlik magies van aard, maar nie goddelik nie. Die goddelike (teenoor die magiese) eienskap is 'n kulturele nuanse op die basiese motief van hulp, maar die motief bly steeds vreemd aan Tipe 922.

Niditch en Doran (1977:193) kom dan tot die gevolgtrekking dat die tradisionele wysheidsverhaal in Daniël 2 grondig hervorm en herbenut is, alhoewel dit nie volledig verlore gegaan het nie. In terme van die struktuur van motiewe volg Daniël 2 die tradisionele orde, maar voeg ook motiewe of inhoudselemente by wat nie normaalweg in die patroon voorkom nie. Die tradisionele eenvoudige tema oor wysheid en sukses verdwyn in die agtergrond as Daniël 2 eerder wys op 'n nuwe vorm waarin die interpretasie van droomsimbole die aanvaarbare norm word om goddelike openbaring te ontvang. 
Die skrywers merk op dat Daniël 4 en 5 'n soortgelyke hervorming van die tradisionele tipe verteenwoordig (Niditch \& Doran, 1977:192). In hierdie verhale kom tradisionele motiewe ook steeds voor, selfs waar dit ontoepaslik binne die huidige boodskap van die werk is.

Niditch en Doran se werk is waardevol as dit die verhouding tussen tematiese elemente en orde in die verhaalpatrone ondersoek, asook die omvang van verhaaltipes bekyk. Hulle poog ook om kriteria te vestig vir die formele analise van Bybelse verhale, asook verhale uit die antieke Midde-Ooste. Deur die omvang van hul ondersoek te beperk, kry die skrywers dit reg om behoorlik op die inhoud van die verhale asook die struktuur van die inhoud te konsentreer.

Dit is ook die eerste poging om tipologiese patrone, wat deur navorsers van volksverhale ontwikkel en beskryf is, te benut. Die Aarne-Thompsontipologie verskaf 'n standaard waarteen die verhale geëvalueer kon word. Dit maak dit moontlik om die onderlinge ooreenkomste sowel as die verskille tussen die drie verhale en ander verhale van die verhaaltipe te ondersoek.

Niditch en Doran meen dat Daniël 2, wat sy basiese struktuur betref, met Tipe 922 ooreenkom, maar wat die motiewe aangaan, groot verskille vertoon. Dit demonstreer die probleme in klassifikasiestelsels wat op temas of motiewe gebaseer is. Die Aarne-Thompson-katalogus wil ruimte maak vir alle temas en variasies op die temas wat in volksverhale voorkom. Elke permutasie en kombinasie van motiewe kry 'n onderskeie katalogusnommer en word 'n "tipe" genoem. Dit veroorsaak dat AarneThompson met 'n groot getal verhaaltipes eindig, terwyl elke tipe slegs 'n klein aantal verhale bevat. ' $n$ Probleem wat daardeur veroorsaak word, is dat motiewe en temas tussen kategorieë saamval.

Sommige verhale kon dus maklik by meer as een verhaaltipe ingedeel gewees het en dit beperk die waarde van die katalogusstelsel. Dit is nie altyd moontlik om te bepaal waar een variant eindig en 'n volgende begin nie. Wanneer die tipologie op strukturele eienskappe gebaseer word, eerder as op temas en motiewe, word dit makliker om groter groepe verhale byeen te voeg. Dit is wat Vladimir Propp (1968) doen as hy die kategorie van "feëverhale" gebruik vir sy analise.

Omdat die Aarne-Thompson-katalogus op die inhoud van verhale gebaseer is, en omdat talle Bybelse verhale van tradisionele verhale verskil, meen ek het die katalogus beperkte waarde vir die analise van Bybelse verhale.

Niditch en Doran sien raak dat Genesis 41 en Daniël 2 van Tipe 922 se beskrywing verskil, maar is nie in staat om 'n tipe daarvoor te identifiseer 
wat albei die verhale beskryf nie. Hulle toon ook nie aan hoe die twee Bybelse verhale aan mekaar verwant is nie, en hoe die twee verhale stadia na 'n nuwe vorm is wat wegbeweeg het van die tradisionele vorm. Hulle slaag nie daarin om aan te toon hoe ander Bybelse verhale wat dieselfde vorm vertoon, hierby gegroepeer kan word nie.

\subsection{P.R. Davies}

Davies (1980:33-48 en 1985:50-55) ondersoek Daniël 1-6 as 'n eenheid in sy artikel wat die eskatologie van die Daniëlboek beskryf. Hy stel voor dat die verhale in twee soorte verdeel word: interpretasie- of uitlegverhale, en verhale van uitredding (Davies, 1980:40). Hy verdeel die verhale op grond van die wyse waarop dit uitdrukking gee aan die soewereiniteit van God, en aan die gedrag van die helde van die verhale. Daniël 2, 4 en 5 lyk na uitlegverhale terwyl Daniël 3 en 6 uitreddingsverhale is.

Davies se klassifikasie op grond van temas lei tot 'n verdeling wat ooreenstem met dié van Humphreys, Collins en Wilson. Slegs sy benaming verskil. Hy poog nie om die struktuur van die onderskeie verhale te identifiseer nie, en ook nie om die patroon van sy twee groepe te beskryf nie.

\subsection{R.R. Wilson}

Wilson (1981:79-95) lewer ook 'n bydrae tot die debat oor die genreprobleem van die Daniëlverhale. Die doel van sy artikel is om die bespreking van apokaliptiek te benader vanuit 'n ander hoek deur apokaliptiese godsdiens in sy kontemporêre vorm te ondersoek. Hy wil dan moderne getuienis gebruik om die verhouding tussen apokaliptiese godsdiens en literatuur in antieke Israel te ondersoek (Wilson, 1981:83). Hy kies die Daniëlboek om die nut van sy benadering te bewys.

Wilson aanvaar die klassifikasie van die verhale as hofverhale (Wilson, 1981:88). Hy aanvaar ook die indeling van die verhale in twee groepe (Wilson, 1981:89). Verder ondersoek hy die strukture van Daniël 3 en 6 onderskeidelik, en stel dan dat dit 'n strukturele patroon volg wat algemeen in burokratiese of "wysheidsirkels" gevind word. Die strukturele patroon in wysheidsirkels is die basiese struktuur van die tipiese martelaarverhaal, behalwe vir die feit dat die helde nie sterf nie. As die helde nie sterf nie, beteken dit egter dat die verhale nie meer martelaarverhale is nie (Wilson, 1981:89).

Die teenstelling, naamlik dat die Daniëlverhale nie martelaarverhale is nie, maar tog is, is verwarrend. Wilson skets die "struktuur" van elke verhaal en vergelyk dit dan met die "struktuur" van die martelaarverhaal. 
Dit is duidelik dat hy die strukture van die Daniël- en martelaarverhale met mekaar identifiseer.

Dit is 'n tekortkoming in Wilson se werk dat hy nooit 'n volledige beskrywing van die basiese struktuur van die martelaarverhaal bied nie. Wat die verhouding tussen die struktuur van die twee verhale, en dié van die martelaarverhaal is, is ook onduidelik. In dieselfde trant argumenteer hy dat die verhale in Daniël 2, 4 en 5 naastenby dieselfde struktuur het en dieselfde boodskap weergee. Dit is dieselfde struktuur wat ook gevind word in die Egiptiese profetiese tekste (Wilson, 1981:91). Hy bied weer eens nie 'n beskrywing van hierdie struktuur nie, maar som slegs die inhoud van individuele Egiptiese tekste op.

\section{Gevolgtrekking}

Dié kort beskrywing van die huidige stand van navorsing toon dat daar nie konsensus oor genreklassifikasie of strukturele patrone bestaan nie. Tog is daar ' $n$ tendens om die verhale in Daniël 2, 4 en 5 saam in een groep te plaas, en die verhale van Daniël 3 en 6 in 'n ander groep. Dit is moontlik dat die navorsers dié indeling bloot intuïtief gemaak het, soos Propp (1968:6) beweer. 'n Strukturele en formele analise sal dit myns insiens bevestig. Wanneer die analise slegs op gedeelde patrone gebaseer word, lei dit tot diverse resultate.

Daniël 1-6 verskaf 'n klein verhaalkorpus wat verrassend problematies blyk te wees vir navorsers wat die strukture bestudeer om dit te klassifiseer. Die gebrek aan 'n gestandaardiseerde genreklassifikasiesisteem bemoeilik die gesprek ook aansienlik.

Die meeste wat gesê kan word, is dat die Daniëlverhale as wysheids- of didaktiese literatuur gelees behoort te word, en dat dit as hofverhale beskryf kan word. Deist (1992:357-359) verdeel die literatuur van oudIsrael in drie kategorieë: liriese literatuur, epiese literatuur en didaktiese literatuur. Didaktiese literatuur is hoofsaaklik die produk van amptenare aan die koninklike hof (Deist, 1992:358). Een van die subkategorieë van didaktiese literatuur is onderwysende verhale. Hofverhale kan as 'n onderdeel hiervan beskou word, met konflik- en wedyweringsverhale as twee vorme van hofverhale.

Wysheidsliteratuur is 'n literêre genre wat algemeen in die antieke Nabye Ooste voorkom, en bevat aanpassings vir 'n suksesvolle lewe binne die gekompliseerdheid van die daaglikse bestaan. Die Daniëlskrywer gee aanwysings vir die Diaspora-Jood hoe om sy lewe in te rig (Humphreys, 1973:211). 
Om die Daniëlverhale in verdere kategorieë te beskryf, maak eers sin as die kategorieë verder ontwikkel en 'n hulpmiddel word waarmee die betrokke teks beter verstaan kan word. Om die Daniëlverhale as wysheidsliteratuur te lees, verskaf aan die navorser egter alreeds hulpmiddels wat ontwikkel is om sowel Ou-Testamentiese as buite-Bybelse wysheidsliteratuur te verstaan.

\section{Bibliografie}

AARNE, A. \& THOMPSON, S. 1961. The types of the folktale: A classification and bibliography. Vertaling van Verzeichnis der Märchentypen (1911) en uitgebrei deur S. Thompson. Tweede uitgawe. Helsinki : Folklore Fellows Communications, no. 148.

BENTZEN, A. 1952. Daniel. Handbuch zum Alten Testament. Second edition. Tübingen : Mohr.

COLLINS, J.J. 1975. The court-tales in Daniel and the development of apocalyptic. Journal of Biblical Literature, 94:218-234.

COLLINS, J.J. 1977. The apocalyptic vision of the book of Daniel. Harvard Semitic monographs 16. Missoula : Scholars Press.

COLLINS, J.J. 1984. Daniel with an introduction to apocalyptic literature. The forms of the Old Testament literature. Volume XX. Grand Rapids : Eerdmans.

COLLINS, J.J. 1985. Daniel and his social world. Interpretation 39:131-143.

COLLINS, J.J. 1993. Daniel. A commentary on the book of Daniel. Hermeneia. Minneapolis : Fortress Press.

DAVIES, P.R. 1980. Eschatology in the book of Daniel. Journal for the Study of the Old Testament, 17:33-53.

DAVIES, P.R. 1985. Daniel. Old Testament Guides. Sheffield : JSOT.

DEIST, F.E. 1992. Ou-Testamentiese literatuur. (In Cloete, T.T., red. Literêre terme en teorieë. Pretoria : HAUM-Literêr. p. 357-359.)

GAMMIE, J.G. 1976. The classification, stages of growth, and changing intentions in the book of Daniel. Journal of Biblical Literature, 95(2):191-204.

GOOD, E.M. 1985. Apocalypse as comedy: The book of Daniel. Semeia, 32:41-70.

HARTMAN, L.F. \& DILELLA, A.A. 1978. The book of Daniel. Manchester : Anchor.

HEATON, E. 1956. The book of Daniel. Torch Bible Commentaries. London : SCM.

HENGEL, M. 1974. Judaism and Hellenism. Volume 1. Philadelphia : Fortress.

HUMPHREYS, W.L. 1973. A life-style for Diaspora: A study of the tales of Esther and Daniel. Journal of Biblical Literature, 92:211-223.

JASON, H. \& KEMPINSKI, A. 1981. How old are folktales? Fabula, 22:1-27.

LACOCQUE, A. 1979. The book of Daniel. Translated by David Pellauer. London : SPCK.

MILNE, P.J. 1988. Vladimir Propp and the study of structure in Hebrew Biblical narrative. Bible and Literature Series. Sheffield : Almond.

NICKELSBURG, G.W.E. 1972. Resurrection, immortality, and eternal life in intertestamental Judaism. Cambridge : Cambridge University Press.

NIDITCH, S. \& DORAN, R. 1977. The success story of the wise courtier: A formal approach. Journal of Biblical Literature, 96:179-193.

PORTEOUS, N. 1979. Daniel. Old Testament Library. Second, revised edition. London : SCM.

PROPP, V. 1968. Morphology of the folktale. Second revised edition. Ed. L.A. Wagner. Austin \& London : University of Texas Press. 
RHOADS, D. \& MICHIE, D. 1982. Mark as story: An introduction to the narrative of a gospel. Philadelphia : Fortress.

SCOTT, R.B.Y. 1971. The way of wisdom in the Old Testament. New York : Macmillan.

WILSON, R.R. 1981. From prophecy to apocalyptic: Reflections on the shape of Israelite religion. Anthropological perspectives on OT prophecy. Semeiea, 21:79-95.

\section{Kernbegrippe:}

Daniëlverhale: literêre genre van

konflikverhale

wedyweringsverhale

wysheidsliteratuur

\section{Key concepts:}

Daniel stories: literary genre of tales of conflict tales of contest wisdom literature 